Tér és Társadalom 19. évf. 2005/3-4. 187-203. p.

\title{
ÁLLAM - ORSZÁG - RÉGIÓ ÉS A VALÓSÁG
}

\author{
(State, Country, Region and the Reality)
}

MEZEI ISTVÁN

Dolgozatomat dr. Tóth Józsefnek ajánlom azzal a megjegyzéssel, hogy - az alábbiakban kifejtendö tények ellenére - az ö álláspontjának érvényesülését szeretném magam is.

Kulcsszavak:

Kárpát-medence határ menti kapcsolatok regionalizálás

A dolgozatban bemutatásra kerülnek azok a nemzetközi gazdasági folyamatok, amelyek új piaci mozgá sokat kényszerítettek a Kârpát-medence népeire, üj politikai határok közé törve a munkamegosztás addigi regionális egységét. Ezt rögzítette a cseh/szlovák politika, amely az új hatärokon belül teremtett 1920-tól immár saját területein belül tartós, Magyarország, illetve a Kârpát-medence többi része felé inkább zárt, mint nyitott munkamegosztást, regionális elkülönülést. Ezért a Kárpát-medence évezredes regionális egysége a múlté.

\section{Bevezetés}

A társadalmi változások térbeli megjelenésével foglalkozó regionális tudományok szerteágazó kutatási témaköreit két végletbe csoportosíthatjuk.

Az egyik nagy kutatási terùlet az államigazgatási területegységek egymáshoz viszonyított helyzetével foglalkozik. Ez teljesen érthető, hiszen a politikai döntéshozásban valós adatokon alapuló elemzésekre kell támaszkodni. Egy ország kủlönbözó területi-közigazgatási egységei között észlelhetö kủlönbségek alapján dönteni lehet a beavatkozás szükségességéröl, a beavatkozás módszeréről, szükség esetén a fejlesztési források átcsoportosításáról. A közigazgatási határoknak ezt a kitüntetett szerepét erősíti az európai uniós tagság, mert a támogatási források odaítélésében láthatóan döntó szerepe van a statisztikai jelentéseknek. Az Európai Statisztikai Hivatal az összehasonlíthatóság érdekében ragaszkodik is a bejelentett téregységek állandóságához, a jelentésekhez, az elemzésekhez használt mutatók azonosságához.

A másik végponton áll az a kutatási irány, amely igyekszik magát függetleníteni az államilag rögzített területegységektől. A valóságos térbeli folyamatokból kiindulva jut el olyan téregységekhez, amelyek a valóságos folyamatok alapján rajzolják ki a tényleges régiókat, a települési vonzások számbavételével. George Benko tanulmánya (1997) ebben a szellemben foglalja össze a globális és lokális térformáló erőkről szóló vitát, megemlítve a nagy tudományos teljesítményeket Christallertől a hálózati szervezödések fontosságát hangsúlyozó Leborgne és Lipietz munkásságáig. 
A kétféle kutatási irány sokszor találkozik, mert természetesen a valóságos történések a kutatásoktól függetlenül zajlanak, és ténylegesen összekötödnek a jelenségek. A közigazgatási határok látszólagos merevsége, változatlansága mögött az „alatta” zajló valós társadalmi-gazdasági folyamatok nem pont ezekhez a téregységekhez igazodnak. Néha kisebb területen, egy-két településen, néha nagyobb területen, egész megyényi, vagy azon is túlnyúló területen.

Példa erre az a korszakváltás, amit a nehézipar válsága, fontosságának csökkenése, illetve a szolgáltatások, a kutatás-fejlesztés megerősödése, felfutása során figyelhettünk meg. Habár a váltást a közigazgatási egységek határaihoz kötödö adatokkal írják le a szakértők, tudjuk, hogy a válsággal sújtott települések csoportjai egyrészt túlnyúltak az állami-közigazgatási határokon, másrészt mellettük közvetlenül is lehettek válsággal nem sújtott települések. Az 1950 körül még virágzó nehézipari, vas- és acélgyártással foglalkozó régiók az 1990-es évekre elvesztették vezető pozícióikat, és sereghajtók lettek.

Ha azokat a régiókat vesszük számba, amelyek 1950 után törtek az élre új gazdasági formációikkal, akkor azt látjuk, hogy új gazdasági erőterek születtek Európában, megint csak a határoktól függetlenül. Ilyenek a regionalista humorral elnevezett Kék Banán, Napfény övezet vagy Kék Csillag formációk (Horváth 1998). Ez utóbbiakhoz tartozó statisztikai körzetek sorrendjében csak minimális változás történt az utóbbi tíz évben (Sechster Periodischer Bericht). Mindez azt mutatja, hogy az állami-közigazgatási téregységek és a valós régióképződés egymást sokszor átfedő, sokszor egymást kizáró folyamatokból áll. Ez az oka annak, hogy egyre többet hallunk a közigazgatási határok merevségén fölülemelkedő régiók fontosságáról, a régiók Európájáról.

A magyar regionális tudomány is szembetalálkozott ezzel a problémával, épp a Kárpát-medence kapcsán. Princz Gyula nyomdokain járva Tóth József vetette föl, hogy a Kárpát-medence egésze még ma is egy régió a jelenlegi államhatárok ellenére. Tóth József elképzelése egy szélesebb, átfogóbb gondolatmenetbe illeszkedik. Európa egészéröl állapítja meg, hogy a tér felosztása, a természetes regionális tagolódás és a politikai határok nem esnek egybe. Országnak nevezve a nagyobb régiókat 17 országot (régiót, nagyobb téregységet) nevez meg Európában. Közülük néhányat fölemlítve nevezzük meg Ibériát, Britanniát, Skandináviát, a Balkánt és természetesen Kárpátiát. Velük szembe állítja az 50 létezö államot Írországtól (Britannia része) Grúziáig (Kaukázia része). A ,régiók Európájában” a természetes regionális együttmủködés, az organikus gazdasági, térbeli elhelyezkedés alapjain folyik a kooperáció.

Ezt a tudományos megfigyelést alátámasztja az Európai Unió politikája, mert kimondott célja a régiók Európájának megteremtése, aminek az érdekében az egyes államok hajlandóak részben feladni szuverenitásukat, hajlandóak kompromisszumokra a regionális együttmủködés előnyeiért cserébe.

A nyugat-európai együttmüködésekről szóló beszámolók, tanulmányok, elemzések megerősítik, hogy valóban csökken a határok szerepe, a regionális együttmüködéseké pedig növekszik. Ennek két fontos következménye van. Egyrészt a nemzeti 
határok szerepének jelentősége csökkent, másrészt a hatalom gyakorlásának bizonyos elemei a nemzetállami szintről „lefelé, a régiók, illetve „fölfelé” az Európai Unió szintjére kerültek. A hatalom megosztásának példáiként hagyományosan a német föderalizmust szoktuk emlegetni, amely most virágkorát éli, de Franciaország is jelentős lépéseket tett a hatalom megosztásának irányába. Az állami feladatok közül egyre többet vesznek át az Európai Unió intézményei, a határokon átnyúló szervezetek, az eurorégiók száma megszaporodott (Süli-Zakar 2003).

Vajon itt, a Kárpát-medencében is bekövetkezik ez a folyamat? Az állampolgári igény a határok megszűnésére, a földrajztudós számítása a régiók föltámadásáról meg fog valósulni?

A továbbiakban a szerző kételyeit fogja megfogalmazni azzal a megjegyzéssel, hogy maga is az állampolgári-földrajztudósi regionális álmok érvényesülését szeretné. A tanulmány három témakört érint. Véleményünk szerint a gazdasági élet (ezen belül a külkereskedelem és a regionális fejlesztés) és a közigazgatás olyan erősen beavatkozott a Kárpát-medence regionális viszonyainak alakításába, hogy nagyon gyengének látjuk a közös régióvá válás esélyeit. Mivel a Kárpát-medencén ma nyolc állam osztozik, Szlovákiát fogjuk példának tekinteni. Szlovákia ugyanis teljes területével Kárpát-medencei állam, a szlovák nép a hajdani magyar állam keretei között alakult ki. A több évszázados együttélés miatt kitüntetetten kell figyelnünk arra, hogy mi történik legközelebbi szomszédunkban.

\section{A gazdasági kapcsolatok teret megosztó szerepéröl}

Kelet-Közép-Európa országainak az első világháborút követően közös problémája volt a nagyhatalmak gazdasági rendszereihez való kapcsolódás, egyáltalán a betagozódás az európai és a világrendbe. Saját akaratuktól függetlenül kellett váltogatniuk igazodási pontjaikat. Ezt a jelenséget átcsapódásnak fogjuk nevezni a következökben. Irodalmi megfelelője ennek a jelenségnek Ady Endre látomása a „kompországról”. Az első világháború után az Osztrák-Magyar Monarchia romjain létrejött (új) országoknak meg kellett, illetve újjá kellett szervezniük kereskedelmi kapcsolataikat, hiszen egy védett, jórészt önellátó piac széttörésével jöttek létre az utódállamok, köztük Csehszlovákia is.

Csehszlovákia legfontosabb külkereskedelmi piacai, habár csökkenő mértékben, de Ausztria és Németország lettek. Az összes célország adatait vizsgálva látható, hogy törekedett ennek az egyoldalúságnak az cldására. Ennek köretkeztében az említett két ország részesedése csökkenni, illetve a táblázatban nem látható egyéb nyugati országok (Olaszország, Nagy-Britannia, Franciaország stb.) fontossága növekedni kezdett. Magyarország és Csehszlovákia között kezdetben élénk árucsere-forgalom zajlott, de 1931-ben hirtelen egyharmadára visszaesett, mert a külkereskedelmi szerződéseket a két ország nem újította meg. Ennek oka az utódállamokban ,szokásos” vámháború volt. 


\section{1. ÁBRA}

Csehszlovákia föbb külkereskedelmi partnerei 1925-1938 között (The Main Foreign Trade Partners of Czechoslovakia between 1925 and 1938)

Export

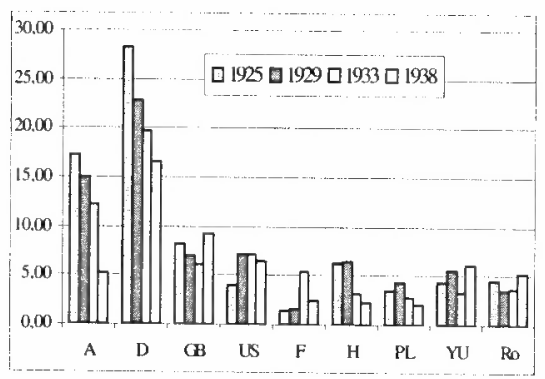

Import

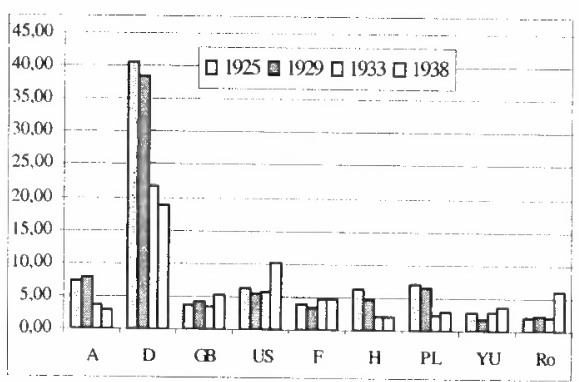

Forrás: Magyarország exportpiacai. 4. füzet, Csehszlovákia.

Ha összevetjük az 1925-1938 közötti évek külkereskedelmi adatait az 1975-1985 közötti adatokkal, akkor erősen szembetúnik az a jelenség, amit csapóhíd-jelenségnek mondhatunk. A két világháború közti német túlsúlyt (1. ábra) szovjet túlsúly váltotta föl (2. ábra), majd a szovjet birodalom összeomlása után megint átcsapódott a kereskedelmi utakon szállított áruk forgalmi fỏ iránya nyugat felé (3. ábra).

\section{2. ÁBRA}

Csehszlovákia föbb külkereskedelmi partnerei 1975-1985 között

(The Main Foreign Trade Partners of Czechoslovakia between 1975 and 1985)

Export

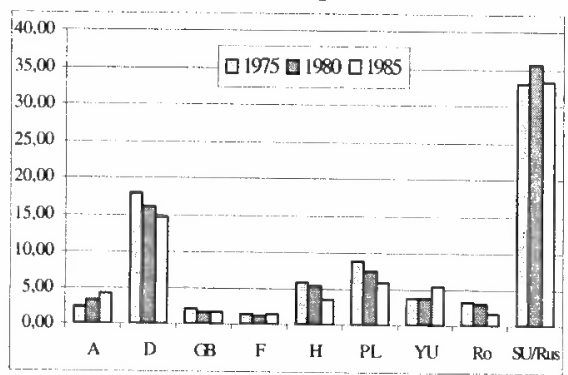

Import

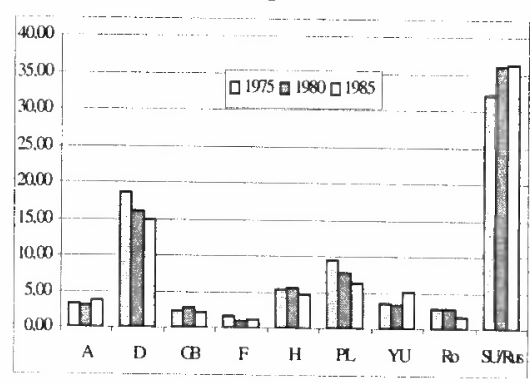

Forrás: Facts $(1985,1991)$.

Megjegyés: A táblázatok német adatai összevontan tartalmazzák a korabeli Nyugat- és Kelet-Németország, valamint Nyugat-Berlin adatait is, de kezdetben a volt NDK volt a meghatározó fél. 1985-re emelkedett azonos arányúra a kelet-, illetve a nyugat-német külkereskedelem aránya. 
Mindebből az Osztrák-Magyar Monarchia felbomlásának gazdasági okára következtethetünk: az európai piac nem türte már a 19. század végén, hogy egy birodalomnyi terület különálló, szinte önellátó gazdasági egységet alkosson. A kapitalista gazdasági verseny, a szabad verseny a nagy, világméretüvé duzzadó monopóliumok korában föl akarta szabadítani, föl akarta törni ezt az elzárkózó piacot. Így került sor a birodalom fölbontására, ami politikailag rengeteg kárt okozott, mert a nemzetiségi elv félretolásával a győztesek hatalmi érdekeit valósította meg, miközben megvalósította gazdasági célját, az akkori európai piacon sok önálló, de egyaránt nyugat felé húzó gazdasági egység létrejöttét.

\section{3. ÁBRA}

Csehszlovákia/Szlovákia föbb küllkereskedelmi partnerei 1990-2000 között

(The Main Foreign Trade Partners of Czechoslovakia/Slovakia between 1990 and 2000)

Export

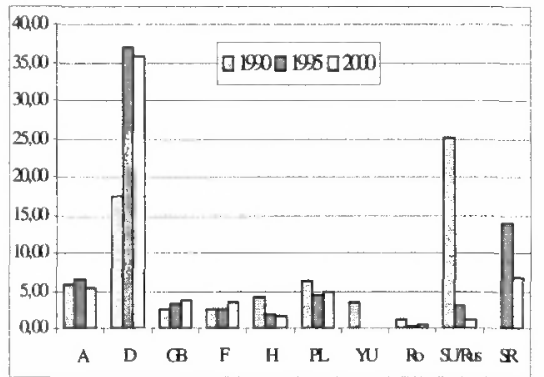

Import

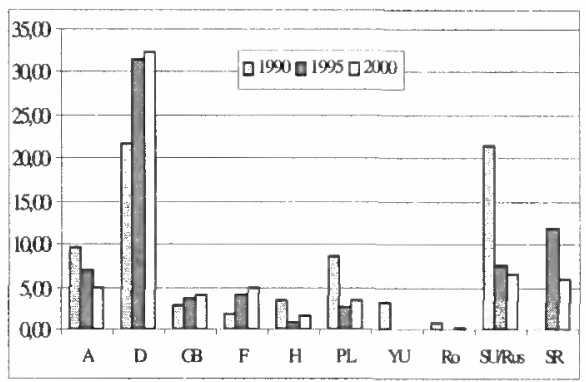

Megjegyzés: A táblázat 1990-es adatai az egységes Csehszlovákia adatai. Az 1995. és 2000. évi adatok a különálló Csehországé.

Forrás: Yearbook of the Cz, 2002., Yearbook of the SR, 2002.

\section{4. ÁBRA}

Szlovákia föbb külkereskedelmi partnerei 1998-2002 között

(The Main Foreign Trade Partners of Slovakia between 1998 and 2002)

Export

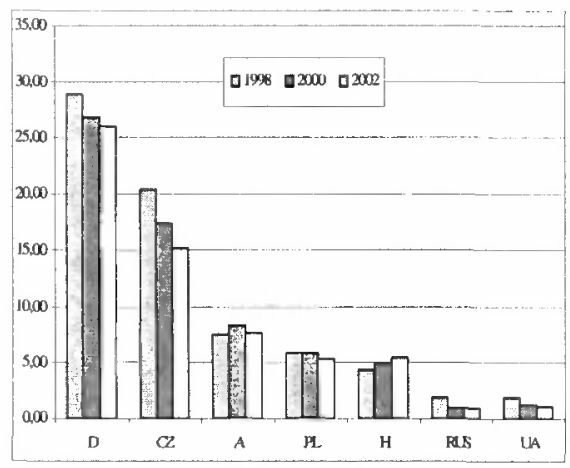

Import

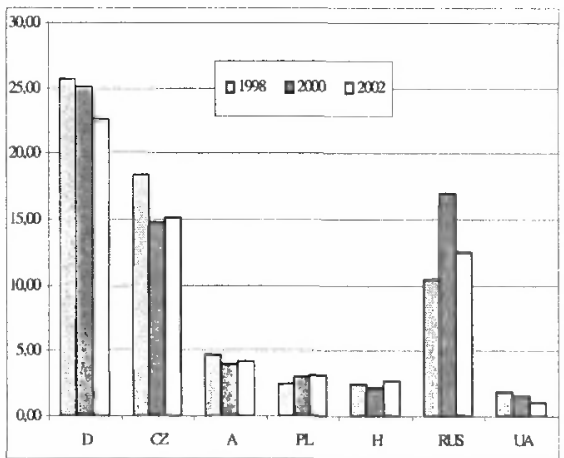

Forrás: Yearbook of the SR, 2002. 
Szlovákia külkereskedelmét napjainkban is a „vízszintes”, a kelet-nyugati irány jellemzi (4. ábra). Legjelentösebb partnerei ugyanis Németország, Csehország és Oroszország. Ez a hagyomány 1918-ban még Csehszlovákiában kezdett kiépülni elsősorban Németország felé, elfordulva a hagyományos, a „természetes”, a regionális (osztrák és fỏleg magyar üzleti-kereskedelmi) kapcsolatoktól. A kommunizmus évtizedeiben természetesen a keleti külkapcsolatok erösödtek fel, ezek jelentőségét megtartotta a Mečiar-éra.

Az önálló Szlovákia külkereskedelmi partnereit tekintve jelentősen különbözik Csehországtól. Egyrészt maga Csehország sokkal jelentősebb partnere, mint Csehországnak Szlovákia, másrészt Oroszország jelentősége is nagyobb. Viszont a nyugati orientáció fölénye itt is vitathatatlan.

Megfigyelhető az adatokból, hogy 1990 után az ország fő külkereskedelmi partnere Németország, viszont a külkereskedelmi tevékenységben érdekelt többi ország nagyobb része is európai. Szlovákia esetében az export 50,3\%-a megy európai országba, 78,8\%-a az OECD országaiba, az import 60,5\%-a érkezik európai országból és $91,5 \%$-a az OECD országaiból. Az Európai Unió lett az az új keret, amin belül az egyes országok (különösen Németország) dominanciája feloldódik a többi tagállam ellenőrző jelenlétében, illetve megerösödött a többi európai országhoz füződő kereskedelmi viszony.

Tanulságos azonban ez az átcsapódás abból a szempontból is, hogy belássuk, nem egyszerüen valamely nép, nemzet, politikai irányzat, állam nacionalizmusáról van szó, amikor ezek az országok egymással viszonylag alacsony mértékủ, alacsony arányú gazdasági kapcsolatot tartanak fenn. Oka ennek a 19. század óta formálódó, majd a világháborúval beteljesedő egymástól való elválás, és az egymástól való függetlenség biztosítékaként inkább a felfüzödés, elöször a nagy európai birodalmak (német, majd szovjet) gazdasági-politikai érdekeinek kiszolgálására, újabban pedig az Európai Unió által diktált európai, illetve a globalizáció által rájuk kényszerített kereskedelmi érdekek logikájára.

1. TÁBLÁZAT
Magyarország külkereskedelmi forgalma a határ menti országokkal és
Németországgal

(Foreign Trade of Hungary and Slovakia with Their Neighbouring Countries and Germany)

\begin{tabular}{lrrrr}
\hline & \multicolumn{2}{c}{ Behozatal } & \multicolumn{2}{c}{ Kivitel } \\
\cline { 2 - 5 } & 1997 & 2004 & 1997 & 2004 \\
\cline { 2 - 5 } Összesen & 100,0 & 100,0 & 100,0 & 100,0 \\
Németország & 26,96 & 29,16 & 29,16 & 31,43 \\
Ausztria & 10,55 & 8,32 & 8,32 & 6,81 \\
Szlovénia & 0,52 & 0,73 & 0,73 & 0,98 \\
Horvátország & 0,17 & 0,23 & 0,23 & 1,29 \\
Jugoszlávia & 0,27 & 0,18 & 0,18 & 0,92 \\
Románia & 0,73 & 1,53 & 1,53 & 3,20 \\
Ukrajna & 1,32 & 1,09 & 1,09 & 1,12 \\
Szlovákia & 1,89 & 1,98 & 1,98 & 1,91 \\
\hline
\end{tabular}

Forrás: KSH alapján saját szerkesztés. 
Az 1. táblázat megint csak a külkereskedelmi forgalom adatai segítségével mutatja be az utódállamok egymás közti viszonyait. A Kárpát-medencében érdekelt államokkal Magyarország szinte minimális kapcsolatot tart fenn, Ausztria kivételével senkihez sem füzi $2 \%$-os forgalom a behozatalt tekintve, ehhez képest kiugró a 3,2\%-os kivitel Romániába.

Európai példát hozva hadd említsem meg Írország esetét. Nemcsak a csatlakozás idején, de a magyar reformkortól kezdődően sokszor vetették össze a két ország nagyon hasonló - az erősebb szomszédnak kitett - sorsát. Eötvös József Szegénység Írlandban (1836) címü útirajzától kezdve a neves ír politikus, Arthur Griffith (1904) írásáig sokan elemezték ezt az alávetett helyzetet. Az írek angolokkal vívott sok évszázados harcainak az 1920-as években lett meg az az eredménye, hogy korábbi gyarmati helyzetükböl kiszabadultak. Viszont a sok évszázados elnyomás ellenére még az 1950-es években is exportjuknak 90\%-a Nagy-Britanniába ment. Mivel az ír politikai vezetés arra a következtetésre jutott, hogy az új ország gazdasága nem fejlödik elég eröteljesen, gazdasági-külkereskedelmi értelemben nyitásról döntöttek. Ennek hatására sok új cég települt az országba, a világkereskedelembe való bekapcsolódásuk eredményeként a Nagy-Britannia felé irányuló exportjuk a csatlakozás évében 50\% körülire, mára 25\%-ra csökkent. Tehát nekünk, a szomszédainkkal való kapcsolatainkban ezt a $25 \%$-os arányt kell összevetnünk a jelenlegi 1-2\%-os arányokkal (Bilek 2004).

Mindebből az következik, hogy Magyarországnak nem sikerült a dualizmus korában kialakult dinamikus központ szerepét fenntartania 1920 és különösen 1945 után. Ennek oka volt az erőszakos határmegvonás, a megszállt helyzet 1945 után, valamint az, hogy az utódállamok politikai döntéssel szándékosan más meglévő dinamikus központokhoz kapcsolódtak, csökkentve ezáltal Magyarország központtá válásának a lehetőségét is. A Kárpát-medence nyolc országát tekintve egy bonyolult háló részei lettünk, de egyelöre nem tudtuk kihasználni központi fekvésünk, népességünk, kultúránk előnyeit. Ahhoz, hogy kapcsolataink a szomszédaink felé is megerösödjenek, hogy pl. Szlovákia és Magyarország között a külkereskedelmi kapcsolatok meghatározó mértékü szintre emelkedjenek, igen szívós, türelmes munkára van szükség. Ehhez adhatna keretet a visegrádi együttmüködés, amit nem véletlenül a magyar politikai gondolkodás talált ki. Elképzelésük jogosságát igazolta azóta a csatlakozási tárgyalások nem várt eredménye, a régi és az új tagállamok egyenlőtlen elbírálása.

A fentiek miatt állítható, hogy Tóth József (2002) elgondolása a szerves régióképződés erejéröl a Kárpát-medencét illetően (sajnos) nem tartható, mert 1920 óta jelentős változások következtek be nemcsak az utódállamok, hanem a világgazdaság életében is, amelyek következtében új regionális kapcsolatrendszerek alakultak ki. Ezeknek az új kapcsolatoknak a fö iránya most már nem északi-déli, nem egy „kisebb tájhoz”, a Kárpát-medencéhez kötődő, hanem nagy léptékekben keletinyugati irányultságú. Ez a gazdasági irányváltás a legföbb befolyásolója a határ menti kapcsolatoknak, emiatt állítható, hogy a határ menti kapcsolatok jóval nagyobb gazdasági erőknek, aszimmetrikus viszonyoknak lettek kiszolgáltatva, s így 
csak a nagy, országos kapcsolatok árnyékában fognak teret kapni, mert nem erösíti őket a várt észak-déli, magyar-szlovák közös regionalizálódás.

Fogalmazzunk reményt adóan: egy rendkívül megerösödött nagytérségi keletnyugati irányú (gazdasági, kereskedelmi) mozgást kell a jövöben észak-dél irányúvá bővíteni. Ez a határ menti kapcsolatok felvirágzásának a feltétele.

\section{A régiófejlesztés teret megosztó szerepéröl}

A szakirodalomban elfogadott az a nézet, hogy vannak természetes, szerves úton létrejött régiók és vannak szándékoltan, állami-politikai akaratból létrejött régiók. Emiatt a kettösség miatt beszélünk regionalizálódásról, amikor az alapvetö társadalmi-gazdasági folyamatok, érdekek alapján a települések, kisebb-nagyobb téregységek között magas fokú integráció jön létre és beszélünk regionalizálásról, amikor intézményi szinten irányított és szabályozott közigazgatási-politikai folyamatról van szó (Süli-Zakar 2003).

Tulajdonképpen visszajutottunk a bevezetöben említett kettősséghez, csak most a valóságos, a térben zajló folyamatok és nem a kutatás szempontjából. A szerves, valamilyen szempontból homogén régiók kifejlődése, megerősödése, tervezésicselekvési együttmüködése a fejlett piacgazdaságokban megfigyelhető folyamat. A szándékolt regionalizálás különféle módozatai pedig inkább Európa keleti felét jellemzik, ahol a mintakövetés, a fejlettek utolérésének igénye jelenti a kényszerító eröt.

$\mathrm{Az}$ újonnan csatlakozott országok mindegyikében közigazgatási reformok keretében formálták meg felsőbb politikai akarattal az új fejlesztési régióhatárokat, meszszemenően szem elött tartva az Európai Unió tanácsait. Példa rá az önkormányzatiság jegyében 1998-ban megreformált lengyel igazgatási szerkezet, ahol részben a régi lengyel hagyományokat élesztették fel, részben azokat szakították szét, amikor létrehozták az új 16 vajdaságot, tulajdonképpen tervezési régiót, ahová hatalmi jogokat is telepítettek. Rendkívül fontos az a körülmény is, hogy a történelmi Lengyelország területéhez képest nagyhatalmi önkénnyel egészen más helyen hozták létre az új államot. Egy sok évszázados regionális fejlődést szabdaltak fel, toltak arrébb néhány száz kilométerrel. Igen nehéz ebben az esetben államról és (régiókból építkező) országról beszélni (Illés 2000).

Ilyen a magyar tervezési-statisztikai régiók ügye is, mert meglévő közigazgatási egységeket vontak össze hatalmi akarattal. Még emlékszünk az 1990 után spontán módon kialakult kistérségi szervezödésekre is, amelyeket az 1996-os önkormányzati törvény tört bele a statisztikai kistérségek rendszerébe. 1998-ban a statisztikai régiók kialakitásakor pedig elsődleges cél volt, hogy NUTS II régióként stabil alapjává váljanak az európai regionális statisztikai megfigyelési rendszernek. Magyarország esetében is rendkívül fontos körülmény, hogy az 1920-as békeszerződés olyan határokat kényszerített ránk, amelyeknek alig volt köze a természetes regionális folyamatokhoz. A vonzáskörzetek szétszabdalására szomorú példákat tudunk felsorolni. 
A történelmi Magyarország tájai közül a Felvidéknek nevezett területnek is - a népek önrendelkezésének fennen hangoztatott elvét félredobva - tölünk függetlenül alakult a sorsa. A Felvidék megnevezés a 19, században jelent meg, akkor a zömmel nemzetiségek által lakott, lengyel határhoz közeli magas hegyeket értették alatta, majd 1920-tól kapott most már politikai-közigazgatási tartalmat. Azóta a mai Szlovákia területének egészét értjük alatta, beleértve a Kisalföld Dunától északra fekvő részét is (Paládi-Kovács 2003). Ilyen értelemben foglalta össze a Felvidékröl szóló tudnivalókat Mendöl Tibor is (1940). Ma a Felvidék megnevezést Szlovákia szinonímájaként használjuk.

A Felvidék - a történelmi Magyarország többi régiókezdeményezéséhez hasonlóan - csak megindult a szerves, modern, polgári regionalizálódás útján, amelynek során a területén élő népek, nemzetek, csoportok nyelvi-kulturális-életmódbeli tarkabarkaságát felváltotta volna egy egységesebb regionális tudat, és a neki megfelelő (közigazgatási) régió, de annak kifejlödését már nem érhette meg. A szlovák politikai-társadalmi mozgalmak gyengesége miatt közös történelmünk folyamán nem alakult ki még a magyar megyerendszer határain belül sem olyan tagozódás, ami nyelvi elhatárolódást tükrözött volna. Voltak északon szlovák többségü megyék, de délebbre már egyre inkább a vegyes nemzetiségüek jellemzők. A nagyhatalmi erőviszonyokat kihasználva haraptak ezekhez a területekhez újabb, tisztán magyarlakta területeket, például a Kisalföld északi részét a Duna vonaláig, mesterségesen hozva létre természetes határt az új állam déli részén.

Az új csehszlovák állam határainak kijelölésekor nem valamilyen már létező szerves régió(k) meglévö, rögzültt, közigazgatásilag is szentesített határaiból formáltak államhatárt, hanem létrehoztak, képeztek egy új államot, amelynek részévé tettek olyan tájelemeket, amelyekből ők maguk törekedtek régiót, társadalmi-gazdasági-etnikaikulturális egységet teremteni. Erre azért kerülhetett sor, mert Magyarország polgári korszakbeli szerves regionalizálódása épp csak megkezdődött, de nem teljesedhetett ki.

Állításom szerint Kelet-Közép-Európára jellemző módon mesterségesen létrehozott új állam maga alakította sikeresen régióvá területét, saját hatalmi eszközeit fölhasználva. 1920 óta Csehszlovákiának, 1993 óta Szlovákiának az a fö törekvése, politikai, gazdasági célja, hogy megbonthatatlan egységgé formálja a megszerzett országot. A hatalmi érdek rajzolta meg ennek az új államnak a határait, és az új állam maga jelölte ki új belső területi egységeit. Maga az új állam akaratlagosan hozott létre egy olyan gazdasági térstruktúrát, amely tér mára egy egymást kiegészítỏ ipari-szolgáltató és egy többnyire mezőgazdasági termékeket előállító komplementer félből tevơdik össze.

Az alábbiakban ezt a komplementer, azaz egymást kiegészítő és ezért egymáshoz szorosan kapcsolódó, összefonódó két gazdasági térfelet mutatjuk be.

Csehszlovákiában az állam megalakulása után egy olyan tartományi rendszer jött létre, ahol a fejlettebb cseh-morva országrészt szolgálta ki a kevésbé fejlett keletỉ tartomány. A polgári korszakban felhalmozódott szlovák sérelmek miatt a kommunizmus évtizedei alatt a terület- és településfejlesztési politika hatására új térségi 
megoszlást kellett kialakítani. A szlovák területeken is eröltetett iparfejlesztés (bányászat, nehézipar, hadiipar) párosult a városfejlesztéssel, aminek a célja a rendszerhủ munkásosztály (és értelmiség) kialakítása volt. A szlovák országrész fejlesztésére elsősorban az 1970-es évekig volt jellemzö a viharos gyorsaság. Az eröltetett iparosítást politikai és stratégiai okokkal magyarázhatjuk. Politikai cél lett a szlovák országrész elmaradottságának felszámolása, katonai stratégiai cél volt a hadiipar fejlesztése. A korábban domináló élelmiszer-, könnyű- és faipar háttérbe szorult, a hadiüzemek meghatározó részét viszont a Németországtól távoli, jól védhetö Vág völgyében fekvő városokba telepítették.

\section{5. ÁBRA}

Hagyományos és új ipari központok Szlovákiában

(Traditional and New Industrial Centres in Slovakia)

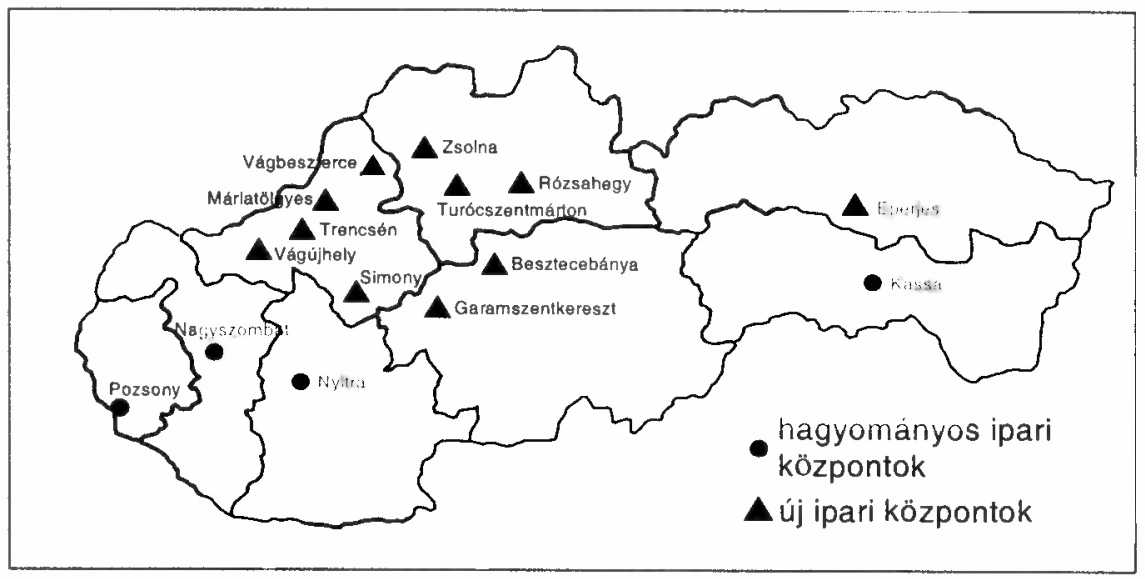

Forrás: Sidó (2004) alapján szerkesztette Mezei István, rajzolta Mády Máté.

Ezzel megváltozott a Felvidék korábbi térszerkezete, mert a hagyományos ipari és kereskedelmi központok jó része már a 19. században, vagy még azelött elvesztette korábbi jelentőségét (Selmecbánya, Körmöcbánya, Késmárk, Löcse), más része továbbra is regionális, sőt országos jelentőségü maradt (Pozsony, Kassa, Nagyszombat, Nyitra). Viszont a nehézgépgyártás eröltetése új ipari központokat hozott létre: Vágbeszterce, Máriatölgyes, Turócszentmárton, Garamszentkereszt, Zsolna, Simony, Vágújhely. A felsorolásból kitünik, amit a térkép szemléletesen mutat, hogy déli város, déli település nincs a felsoroltak között. Dél-Szlovákiában egyedül Komáromban volt a fentieknél kisebb jelentőségủ hadianvaggyártás (Sid 5 2004).

Ez a nehézipar nem szervesült egy általános gazdasági fejlödéshez, idegen maradt az országon belül is. Addig nyújtott foglalkoztatottságot és jólétet, amíg az ország a szovjet érdekszférába tartozott, annak elmúltával válságba zuhant a régio.

Az iparfejlesztés fénykorában zajlott le a korábbi cseh és szlovák komplementer gazdaság módosulása. A két tartomány közötti munkamegosztás megmaradt, de ekkor egészült ki egy Szlovákián belüli új megoszlással. A nagymértékủ szlovákiai 
iparfejlesztés hatására Szlovákián belül jött létre az északi iparvidék és a déli mezögazdasági területek elválása. Ez a különbség fennmaradt, nem változott 1989 után sem, sőt azóta az újabb beruházások tovább erösítik ezt a megosztottságot. Épp a súlyos válságba került nehézipar, hadiipar hatalmas munkáslétszáma kényszeríti a szlovák területfejlesztést arra, hogy a válság enyhítésére ezeket a korábbi ipari központokat fejlessze. A magas munkanélküliség, a koncentráltan jelen lévő nagyszámú munkaerö foglalkoztatása kiemelt fontosságú feladat. A népességkoncentráció, a szakismeretek megléte arra sarkallja a fejlesztóket, hogy a válságból való kilábalás célterülete legyen a volt nehézipari övezet.

Ez a törekvés találkozik az Európai Unió elképzeléseivel is. Az Unió a versenyképesség fokozására helyezi a hangsúlyt, nem az elmaradottság fölszámolására. Ez a fejlesztési elgondolás arra alapoz, hogy ha az innovációs pontokon nő a gazdaság, akkor annak lesz kisugárzó hatása.

A szlovák területfejlesztés kapva kap az alkalmon, és összekapcsolja a válságos, ám magas ipari szakmakultúrával rendelkező körzetének átépítését az Unió által előnyben részesülő innovációs centrummá. Ezt a tervet megkönnyíti az a tény, hogy az EU az egész országot egységesen elmaradott Objektív 1. területnek tekinti, és nem tagolja tovább fejlesztési régiókra. Így szabad kezet kapott a szlovák területfejlesztés is, mert az egész ország egy célterület, azon belül pedig külső ráhatás nélkül választhatja ki a fejlesztendő területeket. Ennek következtében a szlovák Nemzeti Fejlesztési Terv sem tartalmaz belső területi megosztást, azaz nem szól régiókról.

A szlovák területfejlesztés a fentiek miatt átépíti, felújítja, konszolidálja eddigi válságövezetét. Ezt jól példázzák az épüló autógyárak és egyéb üzemek, valamint az öket kiszolgáló infrastrukturális beruházások nyomvonala. Rögzül Szlovákiában a (negyvenes) ötvenes évektől kezdve kialakított belső munkamegosztás az iparosodott, gazdasági értelemben dinamikus, jó infrastruktúrával rendelkező észak és a mezögazdasági termékeket gyártó dél között. Ez a különbség, eltérés, egyensúlytalanság, aszimmetria azonban statisztikailag nem, vagy alig mutatható ki, mert a regionális adatok a kerületek, az önkormányzati megyék szintjén készülnek. Az ipari központok területi megoszlásán pedig látszik, hogy Eperjes kerület kivételével minden kerületben van valamilyen ipari/szolgáltató létesítmény, ami a kerület egészének statisztikai képét megváltoztatja, feljavítja, illetve egy nyugatról kelet felé tartó lejtöt rajzol ki (Bucek 2000).

A térkép alapján látható egy északi irányba húzódó karéj a befektetők által kedvelt települések földrajzi helye szerint (6. ábra). A táblázat a Pozsonyi Kereskedelmi Kamara adatai alapján mutatja meg a befektetök számát kerületenként, s egyúttal azt is, hogy az illetó keruiletben melyik település volt a legkedveltebb helyszín a multinacionális vállalatok számára, hol hajtották végre legtöbben beruházásaikat. A három nyugati kerület (Pozsony, Nagyszombat és Nyitra) elönye vitathatatlan, hozzájuk képest a többi kerületbe csak elszórtan kerültek külföldi vállalkozások. 


\section{6. ÁBRA}

A föbb multinacionális befektetôk Szlovákiában (The Most Important Multinational Investors in Slovakia)

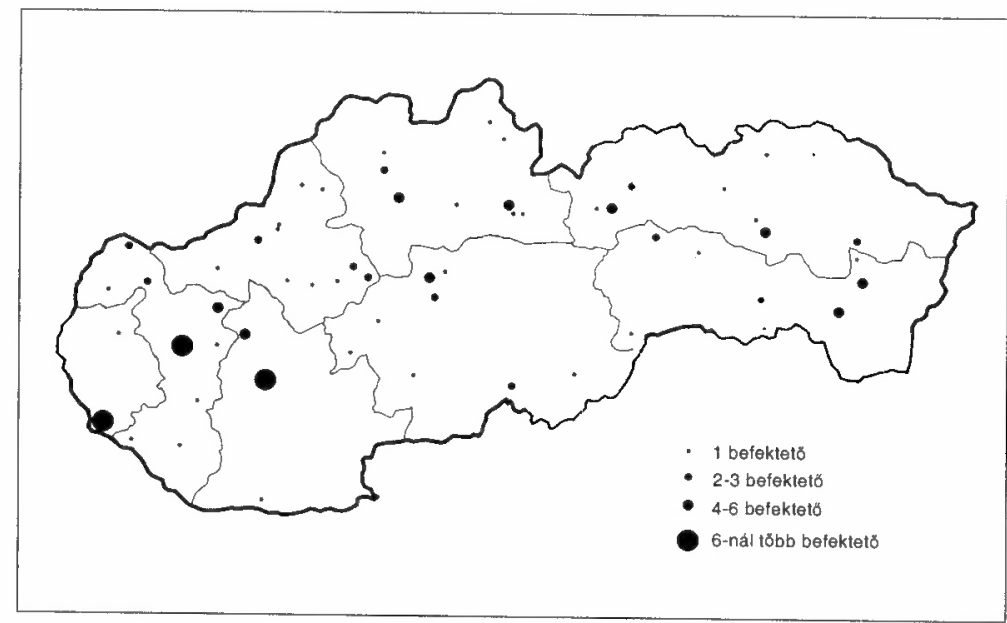

Forrás: Commercial Office. Bratislava. 2004. Szerkesztette Mezei István, rajzolta Mády Máté.

\section{TÁBLÁZAT}

A föbb befektetök kerületenként, és a legtöbb befektetés helyszine (The Most Important Investors According to Regions and the Location of Most Investments)

\begin{tabular}{lclc}
\hline \multicolumn{1}{c}{ Kerület } & Befektetók száma, db & A legtöbb befektetés helyszíne & $d b$ \\
\hline pozsonyi & 15 & Pozsony & 14 \\
nagyszombati & 25 & Nagyszombat & 11 \\
nyitrai & 18 & Nyitra & 10 \\
trencséni & 15 & Privigye & 3 \\
besztercebányai & 13 & Besztercebánya & 4 \\
zsolnai & 20 & Liptószentmiklós & 6 \\
eperjesi & 20 & Eperjes & 6 \\
kassai & 19 & Nagymihály & 6 \\
\hline \multicolumn{1}{c}{$\Sigma$} & 145 & & 60 \\
\hline
\end{tabular}

Forrás: Commercial Office. Bratislava. 2004.

Szlovákia észak-déli irányú megosztottságát érzékelteti az utak mozdíthatatlan és árulkodó hálózata. A meglévő úthálózat is kedvezőtlen volt a déli települések számára, a most épülỏ autópályák pedig kifejezetten hátrányos helyzetet hoznak létre, mert nyomvonaluk határozottan északi, követi a gazdaságfejlesztés által elönyben részesített területeket. Az országhatár innenső, magyarországi oldalán megépült utak nyomvonalával együtt szemlélve az úthálózatot, azt mondhatjuk, hogy a Duna mentén a magyar határ innensỏ oldalán kiépített, az egész ország szempontjából kedvezỏ közlekedési, forgalmi állapotok uralkodnak, a szlovákiai oldalon viszont rendkívül 
hátrányos helyzetben vannak a csallóközi települések, míg az Ipolytól keletre a határ mindkét oldalán közlekedési árnyékba kerültek a települések (7. ábra).

\section{7. ÁBRA}

Egész Szlovákia és Magyarország szlovák határ menti megyéinek úthálózata (Road Network in the Counties Along the Border in Slovakia and Hungary)

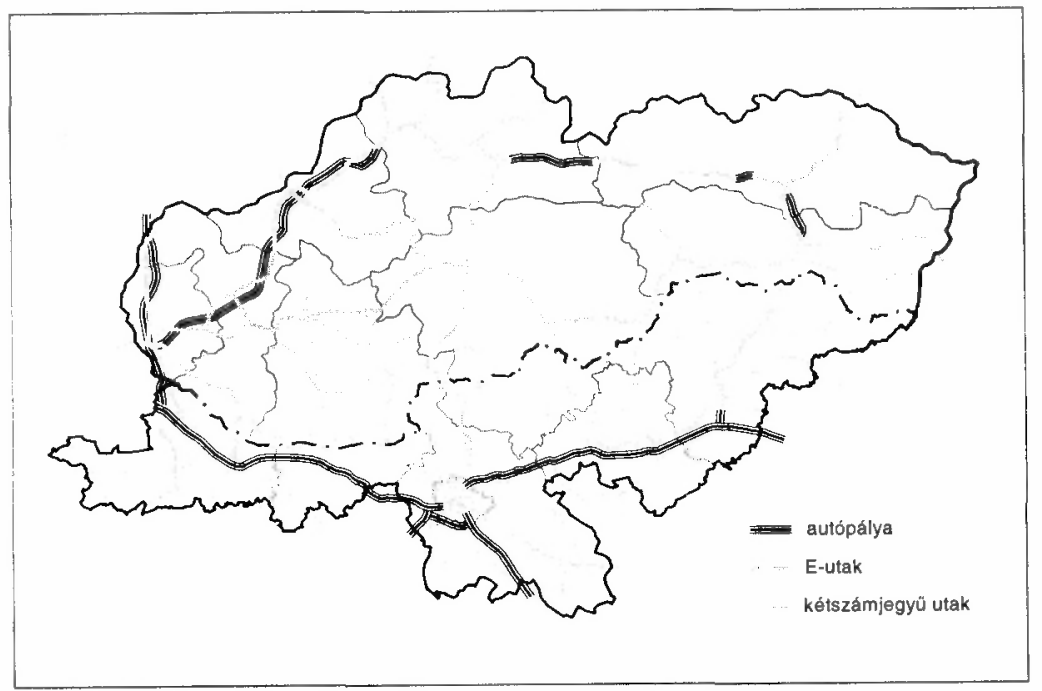

Forrás: Szlovák és magyar autóatlaszok. Szerkesztette Mezei István, rajzolta Mády Máté.

A fentiekben bemutatott több évtizedes szándékolt régiófejlesztési tevékenységnek már megvannak a statisztikailag bizonyítható társadalmi következményei. A területi egységek közötti fejlettségi különbségeket közismert jelzöszámokkal szoktuk érzékeltetni. Ezek a demográfiai, a nemzetiségi, a foglalkoztatási, a képzettségi stb. mutatók, amelyeknek a segítségével szemléltethetö Szlovákia észak-déli megosztottsága. Ha Dél-Szlovákiának a 16 déli járást tekintjük a két nagyváros, Pozsony és Kassa kivételével, a többi 63 járást együtt pedig Észak-Szlovákiának (Horváth 2004), akkor az így kialakított összehasonlítás jól mutatja a komplementer gazdálkodás következményeit. A déli járások mezőgazdasági jellegủek, az északibb járások iparosodottabbak. A két nagy város az északiak adatait is nagy mértékben módosítja, mert esetükben a szolgáltatások szerepe országosan is kiemelkedő központi feladataik ellátása miatt, ennek megfelelően jelentősen kisebb a mezőgazdaságban és az iparban foglalkoztatottak aránya. Ugyanez a helyzet a képzettséget tekintve is, a két városban nagyobb az iskolázottabb népesség aránya. A déli 16 járás lakosai hátrányosabb gazdasági viszonyok között élnek, amely hátrányos gazdasági viszonyoknak már megvannak a demográfiai, a foglalkoztatási, a képzettségi következményei. 
Mezei István : Állam — Ország - Régió és a valóság

Tér és Társadalom 19. évf. 2005/3-4. 187-203. p.

\section{TÁBLÁZAT}

Az észak-déli megosztottság föbb mutatói Szlovákiában

(The Most Important Indicators of the North-Southern Division in Slovakia)

\begin{tabular}{|c|c|c|c|c|c|c|c|c|c|}
\hline & & \multicolumn{3}{|c|}{$\begin{array}{c}\text { Észak-Szlovákia, } \\
63 \text { járás }\end{array}$} & \multicolumn{3}{|c|}{$\begin{array}{l}\text { Dél-Szlovákia, } \\
\text { 16 járás }\end{array}$} & \multicolumn{2}{|c|}{ Szlovákia } \\
\hline & & fö & $\%$ & szórás & $f^{\prime \prime}$ & $\%$ & szórás & $\%$ & szórás \\
\hline \multirow{4}{*}{$\begin{array}{l}\text { Foglalkoz- } \\
\text { tatottak }\end{array}$} & $\begin{array}{l}\text { mezőgazdaság } \\
\text { ipar és építö- }\end{array}$ & 89053 & 4,40 & 324 & 59900 & 7,96 & 2,73 & 5,38 & 1,98 \\
\hline & & 573148 & 28,32 & 7,00 & 188766 & 25,10 & 4,22 & 27,54 & 6,72 \\
\hline & szolgáltatások & 1361318 & 67,27 & 7,27 & 503412 & 66,94 & 4,60 & 67,08 & 7,52 \\
\hline & összes & 2023519 & 100,00 & 0,00 & 752078 & 100,00 & 0,00 & 100,00 & 0,00 \\
\hline \multirow{2}{*}{$\begin{array}{l}\text { Iskolai } \\
\text { végzettség }\end{array}$} & kozzé & 1045497 & 26,46 & 3,14 & 3477 & 23,48 & 1,90 & 25,65 & 1,93 \\
\hline & felsőfok & 343994 & 8,71 & 2,99 & 85776 & 5,79 & 1,80 & 7,91 & 3,68 \\
\hline $\begin{array}{l}\text { Gyermek- } \\
\text { koníak }\end{array}$ & 16 év alattiak & 798942 & 20,22 & 3,13 & 290582 & 19,62 & 1,70 & 20,07 & 2,49 \\
\hline \multirow{3}{*}{ Nemzetiség } & szlovák & 3725153 & 94,27 & 7,26 & 929 & 62,81 & & 85,79 & 10,23 \\
\hline & magyar & 41790 & 1,06 & 2,75 & 489291 & 33,06 & 19,82 & 9,68 & 10,84 \\
\hline & cigány & 56741 & 1,44 & 2,11 & 33218 & 2,24 & 2,12 & 1,67 & 1,64 \\
\hline \multicolumn{2}{|c|}{ Népesség } & 3951421 & 100 & 0,00 & 1479859 & 100 & 0,00 & 0,00 & 0,00 \\
\hline
\end{tabular}

Forrás: Népszámlálás 2001. Štatistický úrad SR.

Fontos megjegyeznünk, hogy az ellentétesnek mondható karakterü tájakat (az északi iparvidéket és a déli mezőgazdasági tájat) a közigazgatási beosztás északdéli irányban kerületekbe zárja, a fejlesztésekkel kialakított vonzáskörzeteket észak-déli irányban fölszeleteli, az összetartozó tájakat szétszakítja, kerületi határokkal rácsozza be az országot.

\section{A közigazgatás teret megosztó szerepéröl}

A Kárpát-medence, így Szlovákia belsỏ viszonyait sem csak a gazdasági kapcsolatok formálják, hanem akaratlagos politikai cselekvések is, amelyeknek az ereje, hevessége nem változott az időben. A szlovák nép államalakítása hasonlóan a többi európai államalakításhoz, más népek, jelen esetben a magyarok rovására történt és történik. Ahogyan a német egységet az osztrákok és a franciák ellenében sikerült megvalósítani, ahogy az olasz egységet az osztrákok ellenében, úgy a korábban nem létező szlovák államot a magyarok ellenében valósították meg. Mivel a szlovákság nemzetté válása gyenge előzmények után ténylegesen a 19. század második felében kezdödött, irodalmi nyelvük, önálló nemzetiségük elfogadtatása pedig szláv testvér-nemzeteik részéröl is vitás volt, emiatt politikai értelemben szükség volt és szükség van ma is egy olyan közös ellenségképre, amely segít ezt az egységet megteremteni, egybetartani. A szlovák politika mind a mai napig ennek a régi, harcias felfogásnak és cselekvésnek a rabja. Ez fejeződik ki a közigazgatási határok alakításában is. Mivel ezt a témakört részletesebben kifejtettük korábbi dolgozatainkban, itt csak egy rövid összefoglalás erejéig érintem ezt a témát (Hardi-Mezei 2003a, 2003b). 
A cseh/szlovák politika az új állam megalakulásának pillanatától, 1920-tól kezdve használja nemzeti célja megvalósításához, a különféle nemzetiségủ országlakosok asszimilálásához eszközként a közigazgatást. Csehszlovákia, az új soknemzetiségü állam, sem ideológiájában, sem igazgatási rendszerében, sem mindennapi gyakorlatában nem vállalta fel ezt a soknemzetiségủ állapotot, sőt a cseh nacionalizmus törekvése az volt, hogy egynemü, egynemzetiségü, azaz csehszlovák nemzetiségủ államot hozzon létre. Az új állam erōs cseh nacionalizmusára (és a szlovák fél gyengeségére) volt jellemző, hogy a szlovákok nemzeti létét is csak hosszú kủzdelem után kezdte elismerni. Mindenesetre az új állam saját hatalmának kiépítése, folyamatos erösítése és a nemzetiségek gyengítése érdekében nagy gyakorisággal változtatta közigazgatásának területi felosztását.

Az igazgatási reformok a kommunista diktatúra bukása után, a rendszerváltás kezdeti reformlépései után (önkormányzatiságot kaptak a települések) egy időre abbamaradtak, mert a csehszlovák belpolitika legfőbb eseményévé a szlovák nacionalisták elszakadási törekvése vált. Az 1993-ban függetlenné vált Szlovákia a nacionalisták központosító elvei alapján fogott hozzá a közigazgatás megreformálásához. 1996-ban új közigazgatási beosztás született.

$\mathrm{Az}$ akkor uralkodó szlovák nacionalista pártok a közigazgatási rendszer átalakításával egyrészt egy központosító politika szervezeti rendszerét akarták kiépíteni, másrészt pedig az ellenzéki választási körzeteket akarták megosztásukkal gyengíteni. Mivel a reformok legkövetkezetesebb hívei a (szlovák) kereszténydemokrata ellenzék és a magyarokat képviselő politikai pártok voltak, a magyarok megosztását több érdek is, nemzetiségi és pártpolitikai érdek is indokolta. A közigazgatás szervezésében a választási-nemzetiségi ellentétek mögött a központosítani akaró nacionalista és a racionális, a reformokat végrehajtani szándékozó modernizációs politikai csoportosulások ellentéte húzódott meg és húzódik meg mindmostanáig. A szlovák nacionalisták és racionalisták szembenállása, illetve - bármilyen furcsa is, de - összjátéka mögött a közigazgatási reformok során a nacionalista központosító hatalmi törekvés győzött a demokrácia alapelve, az önrendelkezés helyett.

Mindez azt mutatja, hogy Szlovákia még mindig nemzetiségi problémákkal küszködik, erejének jó részét még mindig arra pazarolja, hogy minél hamarabb megfeleljen az egységes nemzetállam kritériumainak, és csak ez után tartja fontosnak a maga számára a települések, a népesség, a lakosság kisebb-nagyobb csoportjainak önrendelkezését. A közigazgatás nacionalista célú változtatása szétszabdalja a hagyományos kötődéseket, az összetartozás oly fontos szálait, fölösleges feszültségeket kelt a lakosokban, elvonja a figyelmet a jóléti társadalom építésétỏl, gátolja a társadalmi-gazdasági igényeknek megfelelő regionalizálódást. 


\section{Összefoglalás}

Dolgozatunkban bemutattuk azokat a nemzetközi gazdasági folyamatokat, amelyek új piaci mozgásokat kényszerítettek a Kárpát-medence népeire, új politikai határok közé törve a munkamegosztás addigi egységét. Ezt rögzítette a cseh/szlovák politika, amely az új határokon belül teremtett 1920-tól immár saját területein belül tartós, Magyarország, illetve a Kårpát-medence többi része felé inkább zárt, mint nyitott munkamegosztást. Az elszakadást kikényszerítỏ szeparatív törekvések mozgatórugója a nacionalizmus volt, amely a maga szempontjából egy zárt, teljesen logikus és racionális társadalmi-gazdasági rendszert hozott létre, amely immár önálló és önjáró régióként funkcionál, Tóth József kifejezéseit használva sikerült az államot és az országot egységbe forrasztaniuk. A Kárpát-medence (sajnos) megszűnt egy nagy régiónak (ismét Tóth József kifejezésével élve országnak) lenni, Szlovákia a maga nacionalista szempontjából nézve sikeresen kiszakadt ebböl a nagy egységből, és ezek újbóli regionális összefüződésére igen kicsi a remény.

Magyar-szlovák viszonylatban a határ menti területek emiatt mindkét országban megmaradnak perifériának (illetve a Duna menti sáv Magyarországon dinamikus összekötö sávnak Nyugat-Európával, anélkül, hogy a Duna északi partját sikerülne újból vonzáskörzetének részévé tennie), amely periféria az esetleges területfejlesztési pályázatok mindig alacsony összegébỏl lesz kénytelen bizonyos fejlesztéseket elérni, de amely fejlesztések hatására ezek a perifériák sosem fogják elérni az országos dinamika nagyságrendjét. Így a jövőben a sokkal szerényebb mértékủ, és a szlovák politika által ellenőrzött határ menti kapcsolatok fogják jelenteni az együttmüködés új formáját.

Szlovákia belpolitikai élete tele van belső bizonytalansággal. Ennek alapját az adja, hogy önálló államisággal, saját nemzetállammal történelmi értelemben rövid ideje bír. A szlovák nép eddigi történelme során mindig nagyobb és fejlettebb országok népeinek közösségében élt, nemzeti-politikai önállóság nélkül, emiatt nem szerezhetett elegendö (demokratikus) tapasztalatot a politikai élet szervezésében. Társadalma és gazdasága is fejletlen volt abban az értelemben, hogy a szlovák nép szállásterülete mindig a nagyobb országok (Magyarország, Csehszlovákia) perifériáját jelentette. Ezekben az országokban a társadalmi-gazdasági-kulturális központok, elsősorban a városok lakói a domináns nemzet képviselői voltak, így tehát a tulajdonosok, a vezető tisztviselök magyar, illetve cseh származásúak voltak, vagy olyan szlovákok, akik ezekhez a nemzetekhez asszimilálódtak.

Ez a gazdasági-politikai tapasztalatlanság magyarázhatja azt az erős etnocentrikusságot, ami cselekedeteiket mozgatja. Ez az akadálya annak, hogy az önállóság, sőt a demokratikus viszonyokat szorgalmazó nemzetközi köriilmények ellenére sem tudnak egyelöre egyenrangú kapcsolatokat kialakítani az országalkotó más nemzetiségekkel. Politikai életük középpontjában folyamatosan nemzeti életulk veszélyeztetettsége áll. Az a félelem mozgatja a szlovák politikai eröket, hogy elveszítik nemzeti identitásukat, hogy elveszítik terủleteiket. Ez a szlovákokban meglévő félelem agresszivitásban nyilvánul meg, ami a más nemzetiségủekböl védeke- 
zést, mégpedig egyik végletként elköltözést, másik végletként asszimiláciôt vált ki. Ez a magatartás fölerösödik olyan korszakokban, amikor a kisebbségben élők felé a nemzet nagyobb része nem nyújt védő kart.

Az Európa egyesítéséért fáradozó kereszténydemokrata politikus, Robert Schuman (1991) egyik írásának ez a címe: Európa szétdaraboltsága idejétmúlt abszurditássá vált. Vajon mondhatjuk, hogy a Kárpát-medence szétdaraboltsága idejétmúlt abszurditássá vált? A győztes Franciaország a legyözött Németországgal kereste a megbékélés lehetőségét. Az évszázadok óta tartó egymás elleni könyörtelen harc módszerét akarta felváltani a gyöztes ország az együttmüködésre. Robert Schuman Konrad Adenauerrel összefogva keresett és talált egy olyan Achillespontot, ahonnan kiindulva megkezdték az Európai Unió fölépítését. Ez volt a Szénés Acélközösség megteremtése. Ami korábban ádáz gazdasági-kereskedelmi viták tárgya volt a két szomszédos nép között, ettől kezdve jelképesen is és valóságosan is az együttmúködés kiindulópontja lett.

Ismét fogalmazzunk reményt adóan: a határ menti sok apró kapcsolatnak, jelképes és tényleges hídépítésnek, ösvények, utak felújításának, a testvérvárosi és civil kapcsolatoknak, az eurorégiók együttmüködésének kell, hogy legyen eredménye. Régiók közötti, önrendelkezésen alapuló együttmüködés.

\section{Irodalom}

Benko, G. (1997) A regionális fejlődés útjai: globálistól a lokálisig. - Tér és Társadalom. 2. 1-16. o.

Bilek P. (2004) A korábbi bövítések tapaszalatai Magyarország számára: külkereskedelem. ICEG Európai Központ. 6. Munkafüzet. www.icegec.org

Bucek, M. (2000) Depressed Regions - or Depressed Regional Policy? 10 years of Slovak experience. Informationen zur Raumentwicklung. 7-8.

Griffith, A. (1904) The Resurrection of Hungary: A Paralell for Ireland.

Horváth Gy. (1998) Európai regionális politika. Dialóg Campus Kiadó, Budapest-Pécs.

Hardi T.-Mezei I. (2003a) A racionalizmus és a nacionalizmus küzdelme. Eurorégiók a magyar-szlovák határon. - Comitatus, szeptember. 67-74. o.

Hardi T.-Mezei I. (2003b) A szlovák közigazgatás és területfejlesztés aszimmetriái. - Tér és Társadalom. 4. 143-164. o.

Horvăth Gy. (szerk.) (2004) Dél-Szlovákia. MTA RKK-Dialóg Campus Kiadó, Budapest-Pécs.

Illés P. A. (2000) A lengyel közigazgatási reform kritikája. - Bárdi N. (szerk.) Konfliktusok és kezelésük Közép-Európában. Teleki László Alapítvâny, Budapest. 245-260. o.

Magyarország exportpiacai. 4. füzet, Csehszlovákia. A Magyar Királyi Külkereskedelmi Hivatal Kiadványa. Bp., 1934.

Mendöl T. (1940) A Felvidék. Magyar Szemle Kincsestára, Budapest.

Paládi-Kovács A. (2003) Tájak, népek, népcsoportok. Válogatott tanulmányok. Akadémiai Kiadó, Budapest.

Schuman R. (1991) Európáért. Pannónia Könyvek. Fordította: Tót Éva.

Sechster Periodischer Bericht über die sozio-ökonomische Lage und Entwicklung der Regionen. In: http://europa.eu.int/comm/regional_policy/sources/docoffic/official/reports/toc_de.htm

Sidó H.Z. (2004) Szlovákia gazdaságának változásai és területi jellemzői. - Jobbágy I. (szerk.) Válogatott tanulmányok Szlovákia gazdaságföldrajzához. Pont Kutatóintézet, Komárom. 51-91. o.

Süli-Zakar I. (szerk.) (2003) A terïlet- és településfejlesztés alapjai. Dialóg Campus Kiadó, Budapest.

Tóth J. (2002) Államok és országok az egységesülö Európában. - Szónokyné Ancsin G. (szerk.) Határok és az Európai Unió. Nemzetkőzi Földrajzi Tudományos Konferencia. Szeged. 8-17. o. 